\title{
Comparing Species Composition and Planting Trends: Exploring Pest Vulnerability in Toronto's Urban Forest
}

\author{
Jennifer Vander Vecht and Tenley M. Conway
}

\begin{abstract}
Urban forests represent a valuable resource for cities but are not without costs. These costs can include time, money, and the loss of beneficial services as results of pest infestations. Knowledge of an urban forest's tree species composition and vulnerability to pests is needed to help managers enhance services delivered, while minimizing expenses over the long-term. Recent research has explored the impacts of individual pests on urban forests, but less attention has been given to the overall pest vulnerability. In this research, tree genera currently prevalent and commonly planted in Toronto, Ontario, Canada, were analyzed using a pest vulnerability matrix to explore how the city's urban forest species composition and pest vulnerability may be changing. Current tree species composition was derived from existing inventory data, while the planting trends of a variety of local actors were determined through surveys and interviews. Results indicate there is somewhat limited diversity in current street and non-street tree populations, as well as a number of common tree species that have severe pest vulnerabilities. While new plantings replicate some current composition and pest vulnerability issues, several less common species are also being planted. As a result, overall pest vulnerability should decrease in the future, while some ongoing management concerns remain.

Key Words. Canada; Ontario; Pest Vulnerability; Pest Vulnerability Matrix; Planting Trends; Species Diversity; Survey; Toronto; Tree Pests; Urban Forests.
\end{abstract}

Urban forests make significant, positive contributions to cities and their residents through myriad health, social, environmental, and economic benefits (Tyrväinen et al. 2005). Managing this resource, however, is not without costs. Urban forests are associated with disservices, including the monetary, time, labor, and carbon costs of tree planting, removal, and care (Escobeder et al. 2011). Effective and strategic management of urban forests can help to minimize these costs while maximizing the benefits trees bring to a city. An important element of good management is accounting for species diversity, as the composition impacts associated services and disservices. In general, higher diversity is associated with improved ecosystem service provision (Gamfeldt et al. 2012), and decreased risk of major losses due to insect and disease outbreaks (Raupp et al. 2006; Laćan and McBride 2008).

Pest vulnerability is an important issue to address in urban forests because these forests generally have an over-dominance of a select number of tree species and genera (Laćan and McBride 2008). The danger with this limited diversity is that large sections of an urban forest can be rapidly lost in the event of an outbreak affecting a highly prevalent species or genera (Laćan and McBride 2008). Losses due to pest outbreaks not only decrease the structural and functional value of an urban forest, they also increase management costs as diseased, dying, and dead trees have to be treated, removed, and/or replaced.

Investigations into urban forest species composition are often limited to street tree populations (Sun 1992; Raupp et al. 2006; Sjöman et al. 2012; Subburayalu and Sydnor 2012). However, species composition on private property is likely different from public lands as a result of differences in the knowledge, goals, and actions of key actors engaged in private property tree planting. The literature examining urban forest species composition has also given limited consideration to how the composition may be changing based on what species are currently being planted and how the relevant local actors influ- 
ence those planting trends. Finally, while the impact of specific pests has received considerable attention (Poland and McCullough 2006; Harwood et al. 2011; Vannatta et al. 2012), less emphasis has been placed on overall urban pest vulnerability as a result of current and potential future tree species composition.

This research examines the current and future species composition of public and private trees in Toronto (Ontario, Canada), with a goal of understanding current and potential future vulnerability to pests. Current species composition was determined using two existing tree inventories, while potential future composition was examined by identifying trees currently being planted through the use of surveys and interviews. Pest vulnerability was assessed using basic diversity management guidelines and a modified pest vulnerability matrix, originally developed by Laćan and McBride (2008).

\section{Study Area}

The City of Toronto (Figure 1), located in southern Ontario, Canada, has a population of 2.79 million people in $641 \mathrm{~km}^{2}$ of land area (City of Toronto 2013a). Toronto is located in the eastern edge of the deciduous forest region of Ontario, also known as the Carolinian Forest zone (Kershaw 2001). The region has a moist, temperate climate, with hot and humid summers and mild winters. The native forest of the region is dominated by sugar maple (Acer saccharum) and American beech (Fagus grandifolia), punctuated by Carolinian tree species such as tuliptree (Liriodendron spp.) and Kentucky coffeetree (Gymnocladus dioicus) (Kershaw 2001).

Based on 2008 data, Toronto has an approximate total canopy cover of $20 \%$, with trees concentrated in the ravine and valley systems (City of Toronto 2011). The majority of the urban forest occurs on private property, approximately 60\% (6.1 million trees); another $34 \%$ of trees (3.5 million) are found in parks or in natural areas; and $6 \%$ of the forest is made up of approximately 600,000 city street trees (City of Toronto 2011). More than $45 \%$ of the existing tree population is estimated to have been planted (rather than naturally regenerated), with even higher proportions on certain private property types, especially residential (Nowak 2012). This demonstrates that tree planting is a significant force affecting Toronto's urban forest.

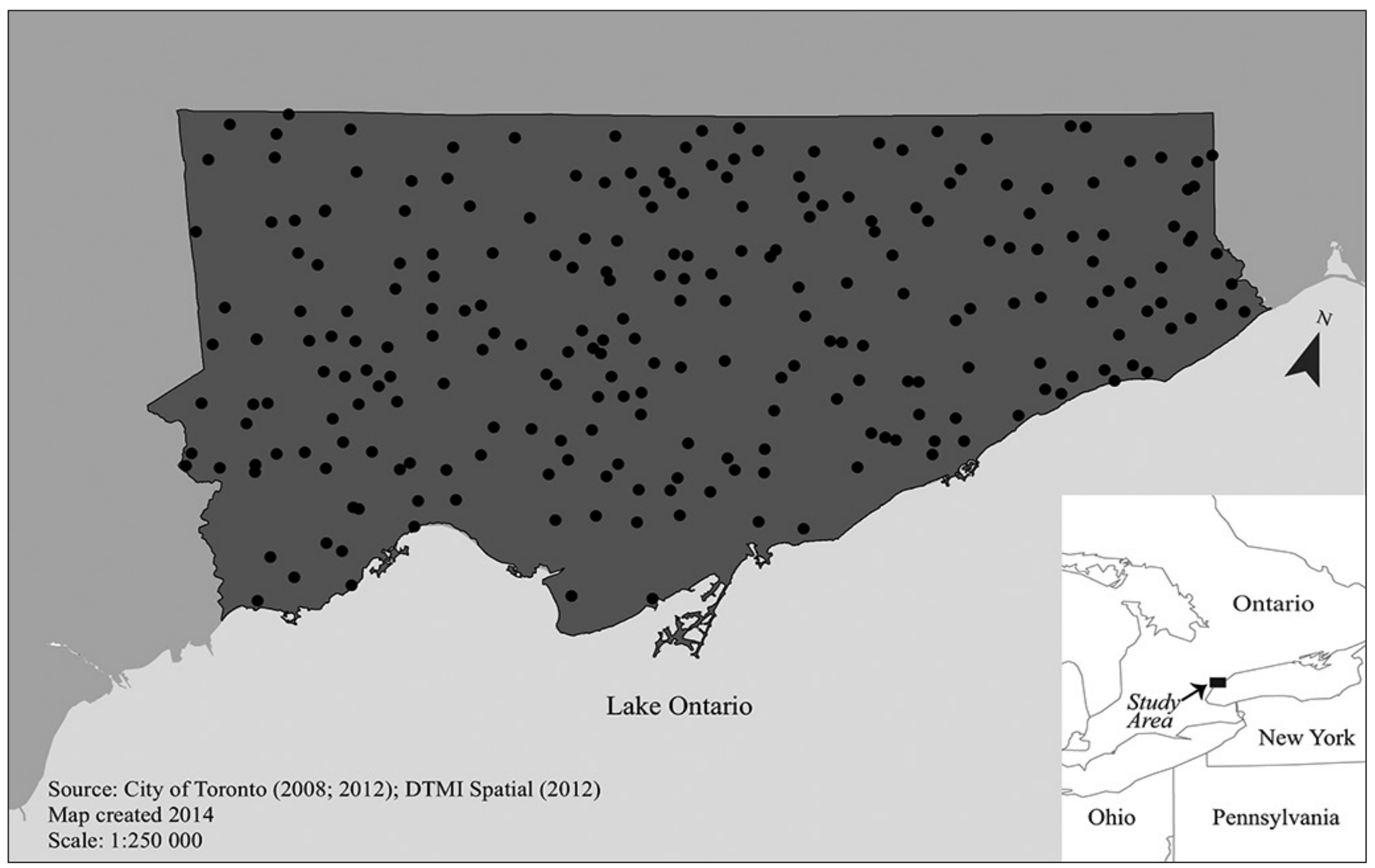

Figure 1. The City of Toronto, Ontario, Canada. Points represent the locations of i-Tree plots used for this study. 


\section{METHODS}

\section{Current Species Composition}

The current species composition of Toronto's urban forest was identified from two preexisting citywide inventories: the Toronto street tree inventory, and the $2008 \mathrm{i}$-Tree sample inventory. The street tree inventory was obtained through the City of Toronto's open data website and contains spatial and botanical information (e.g., species, diameter at breast height) for Toronto's city-owned trees located on road allowances. The data were acquired in December 2012, last updated by the city in March 2012. Users downloading the data are warned that there may be inaccuracies and that some data may be out of date as the city only updates the street trees that are worked on in a given year (City of Toronto 2012). Acknowledging these issues, the data set represents the most comprehensive inventory of all the street trees in Toronto.

The $2008 \mathrm{i}$-Tree data is based on a citywide sampling effort through the use of the i-Tree Eco model (formerly UFORE; www.itreetools.org). Toronto initially selected a total of 435 plots using a spatially stratified random sampling approach, 407 of which were ultimately sampled (the remaining 28 were not accessible) (City of Toronto 2011). Of all the plots sampled, 276 contained trees. The i-Tree data included text files with plot and botanical information, as well as shapefiles representing the geographic location of the center point of each sample plot.

For both data sets, the information used for analysis in this research was species and geographic location. There was limited overlap between the data sets, occurring only where street trees were sampled in the i-Tree inventory. In the interest of minimizing overlap, street trees were removed from the i-Tree data (169 trees in total), which also resulted in the removal of 33 plots from the analysis.

Diversity of the current composition was assessed in two ways. First, genera that exceeded $5 \%$ of the population were identified. The threshold of $5 \%$ was chosen because the City of Toronto uses a 5-10-20 rule to help guide species diversity in the city's urban forest. Under this rule, no more than $5 \%$ of the population should be a single species of trees, no more than $10 \%$ a single genus, and no more than $20 \%$ a single family. While this analysis occurs at the genuslevel, $5 \%$ was used as the threshold for analysis in order to be conservative and look for potential future concerns, not just genera that are already present at problematic levels.

Second, the inverse of Simpson's diversity index (inverse SDI) was calculated. Inverse SDI was chosen following the work of Sun (1992) because it gives a measure of diversity and evenness that is easily compared to the 5-10-20 guideline. The formula for the inverse SDI is:

$$
\left[\Sigma \mathrm{N}_{\mathrm{i}} \bullet\left(\Sigma \mathrm{N}_{\mathrm{i}}-1\right)\right] /\left[\Sigma \mathrm{N}_{\mathrm{i}}\left(\mathrm{N}_{\mathrm{i}}-1\right)\right]
$$

where $\mathrm{N}_{\mathrm{i}}$ is the number of individuals in the ith (1, $2,3 \ldots$ nth) group (genus) and $\mathrm{N}$ is the total number of groups in a particular population (Sun 1992). Larger inverse SDI values indicate greater diversity. When interpreting these inverse SDI results in light of the 5-10-20 diversity guideline, an inverse SDI value of 10 or more would broadly indicate that the desired genera diversity has been reached. Specifically this means that out of 10 random samples containing two trees, one or less is expected to have two trees belonging to the same genus (Sun 1992).

\section{Toronto's Tree Planting Trends}

The planting-related activities of various actors were examined to represent a wide spectrum of individuals, business, and organizations impacting the future composition of the urban forest. The goal was to assess as much of the planting occurring on public and private property as possible. Ultimately four types of actors were included: landscape architects, non-profit organizations (NPOs), garden centers and nurseries, and city urban forestry staff. Lists of the most commonly planted or sold trees were then compiled from the surveys and interview results of each actor.

Landscape architects work at both large and small scales in Toronto, planning exteriors for individual residential properties as well as for largescale developments. The expectation was that landscape architects often include trees in their design. As such, they would be a valuable group to survey to gain perspective on what trees are commonly planted on various property types, including for private citizens and construction contractors.

NPOs were included in the research because there are several organizations throughout the city actively engaged in increasing the quality and quantity of the urban forest, both citywide and within 
specific neighborhoods and watersheds. These organizations, over time, may plant a relatively substantial number of trees, thereby influencing the overall species composition of the forest. Additionally, the City of Toronto's urban forestry website directly refers people interested in planting a tree on their property to NPOs involved in tree planting in the city. In the context of this research, the NPOs invited to participate operate citywide rather than having a focus on a particular region in the city.

Garden centers and nurseries play an important role in shaping the species composition of an urban forest. And although the effect of the nurseryindustry may be significant, investigations into its influence are only just beginning (Pincetl et al. 2013). Toronto's garden centers and nurseries both source and limit the plant material available in the city to some extent. They are gatekeepers for tree diversity, as what is available to customers limits what can be planted (Pincetl et al. 2013). The goal of contacting garden centers within (and immediately close to) the municipal boundaries of Toronto was to gain an understanding of what tree species are most commonly sold at these businesses. This information should provide insight into what is being planted on residential property in particular. Whereas other types of tree planting actors (such as landscape architects, developers, contractors, and NPOs) use garden centers and nurseries as well, these larger entities also have access to wholesalers or other larger scale suppliers operating at the provincial, national, and international levels. Toronto residents, however, are more restricted to buying their trees from local businesses, such as those included in this research.

Lastly, the city's Urban Forestry Department was included to gain insight into planting trends at the municipal level. As the municipal share of the urban forest is managed under a coordinated umbrella, with planting centralized to a single unit in the department, gaining a clear understanding of municipal planting trends was relatively straightforward and reliable. Street and other city-owned trees do not make up the majority of the urban forest, but they are some of the most visible urban trees and are the ones that people often interact with and receive benefits from. As such, they are a significant part of the urban forest.

The first three actors were contacted using an online survey or a combination of online and mailed paper surveys between March and October 2013. In all cases, a multi-contact approach was used, with up to four contacts, to increase participation rates (Dillman 2007). While each survey was tailored to the specific actor, they all inquired about commonly planted (or sold, in the case of garden centers) tree species.

A total population of 111 landscape architects working in Toronto was identified using the Ontario Association of Landscape Architects (OALA) website search engine. The OALA is the registering body for landscape architects in Ontario, administering the provincial licensing exam. The landscape architects identified through this search would be active, full members of the association. All identified landscape architects were invited to participate in the survey, excluding those working for city government to minimize overlap with information gathered from the city. Where multiple landscape architects worked at a single firm, one individual was randomly selected to be contacted in order to avoid overwhelming individual businesses. In a few instances, landscape architects referred the survey to a colleague whom they felt was more suited to respond to the specific questions.

NPOs that operate citywide and were engaged specifically in treeplanting were selected to participate in the online survey; only two organizations met these criteria. They were personally contacted to determine interest in participating, with both organizations completing the survey.

A list of potential participant garden centers and nurseries in the City of Toronto (and the surrounding area) was compiled using DMTI Spatial's Enhanced Points of Interest (EPOI) database. DMTI Spatial is a company that compiles and sells location-based data. The list was modified through the addition of some businesses based on Yellowpages $^{\circledast}$ and Google ${ }^{\circledast}$ searches. Other businesses were removed because they were incorrectly categorized as garden nurseries, were no longer in business, or did not sell trees. A total of 20 garden centers located within Toronto or close to the city boundaries were identified and invited to participate. Large chain stores that have seasonal garden center departments, such as Home Depot and Loblaws, were not included in the research. It was felt that, as large national or international firms it would be difficult to determine Toronto-specific variations in tree sales given they generally sell only a lim- 
ited number of trees. However, these businesses do reflect important sources of vegetation in an urban center and should be included in future research.

Information about how the city manages tree plantings was obtained through a series of e-mail communications (occurring from February to October 2013) with R. Vendrig, the supervisor of Tree Nursery and Natural Resource Management in the Urban Forest Renewal section of the Urban Forestry Department. These communications culminated in a semistructured interview that took place in June 2013.

\section{Pest Vulnerability Methods}

To compare current and future pest vulnerability, a straightforward, previously developed matrix that visualizes interactions between tree pests and tree genera was used. Laćan and McBride (2008) developed the pest vulnerability matrix (PVM) for northern California, U.S., by obtaining and aggregating pest and host information for tree families commonly found in California and assigning severity classes to pests and diseases (Laćan and McBride 2008). Pests and diseases were organized into complexes to increase the visual readability and practicality of the matrix (Laćan and McBride 2008).

The PVM was obtained from its original authors and contained information on more than 100 tree pests and more than 150 tree genera (Laćan and McBride 2008). Interactions between relevant pests and tree genera had been assigned to severity classes based on the management importance of the pest. Low severity indicates problems that typically cause little damage and rarely require intervention; moderate severity indicates problems that are not usually lethal but often require intervention due to damage that is unsightly or that might lead to problems over time; and severe are those that always require management action, typically because of the lethal nature of the insect or disease, and less frequently where problems are not lethal but are unacceptable to people and indirectly lead to mortality through premature tree removal (Laćan and McBride 2008). The matrix also includes emerging problems to encompass potential upcoming threats, primarily invasive non-native species and those pest species with expanding ranges.

Using the original matrix as a base, the PVM was modified for Toronto, drawing on information from several sources: the Ontario Ministry of Natural
Resources (OMNR 1991), the City of Toronto's Forest Health Care website (City of Toronto 2013b), the University of California's Integrated Pest Management website (www.ipm.ucdavis.edu), and relevant resources and literature (Sinclair et al. 1987; Haack and Acciavatti 1992; Waldron 2003; Czerwinski et al. 2006; Schall and Davis 2009; Natural Resources Canada 2011; Dykstra and Sabourin 2012; Plant Disease Diagnostic Clinic 2013.) A semi-structured interview with J. Ric, the supervisor of the Forest Health Care (FHC) unit in Toronto's Urban Forestry Department, was also conducted to gain a sense of general and specific pest concerns in the City of Toronto, as well as for feedback on the relevancy and accuracy of the PVM for Toronto's pest and tree interactions.

In the interest of making the matrix cleaner and easier to interpret, some tree genera columns were omitted from the completed matrices. This was done to account for genera that were noted in surveys but are not classically considered trees or woody shrubs; using Farrar's (1995) Trees in Canada as a reference, only trees and shrub genera included in this text were retained in the matrix for analysis. This ultimately affected only a few genera noted in the garden center surveys.

When comparing the current composition to the planting trends for each tree population, results obtained from Toronto's Urban Forestry Department stood in as street tree planting trends, and the results from landscape architects, NPOs, and garden center surveysweretaken tobethetrendsfornon-street trees.

\section{RESULTS}

\section{Current Species Composition}

The street tree population in Toronto has relatively limited diversity, with $60 \%$ of the over 500,000 street trees in the database represented by five common genera (Table 1). Acer is by far the most common street tree, representing onethird of all street trees. This is also the only genus that exceeds the $10 \%$ threshold, with Gleditsia, Tilia, Picea, and Fraxinus all representing between $5 \%$ and $10 \%$ of the street tree population.

Five genera also comprise more than $5 \%$ of the non-street tree urban forest (Table 1), with three in common with the street tree genera. Again, Acer is the most common genera, while Thuja is also above the $10 \%$ threshold. Thuja, however, is not par- 
ticularly significant to the urban forest, as its high occurrence comes primarily from its common use as a hedge species (City of Toronto 2011). Faxinus, Prunus, and Picea are each between 5\% and 10\% of the total non-street tree population. Based on the inverse SDI, non-street trees have higher overall diversity, although both populations are below the recommended threshold of 10\% (Table 1).

When the city's urban forest is explored below the city level, a few additional genera emerge as common within one or more of the four management districts in the city. For street trees, Malus, Pinus, and Quercus are common (above 5\%) in one or two districts in Toronto. For non-street trees, Ulmus, Gleditsia, Populus, and Pinus are also common in one or more district, but not above $5 \%$ citywide.

\section{Tree Planting Trends}

Table 2 shows basic characteristics and participation rates of the four actors surveyed or interviewed. Seventy-six percent of landscape architects indicated that their designs and plans include tree planting nearly all the time, and an additional $22 \%$ indicated that their plans include trees at least half of the time. The two NPOs surveyed collectively planted approximately 5,200 trees in Toronto last year, and both

Table 1. Common tree genera citywide. Dashes indicate the proportion of the genus is below $5 \%$.

\begin{tabular}{lll}
\hline Genus & Street trees & Non-street trees \\
\hline No. of trees in analysis ${ }^{z}$ & 529,849 & 2,505 \\
Tree density & $92.3 / \mathrm{km}$ road & $10.3 / 400 \mathrm{~m}^{2}$ plot \\
No. of genera & 64 & 47 \\
SDI & 7.26 & 9.37 \\
& & \\
Acer & 33.12 & 23.39 \\
Gleditsia & 7.22 & - \\
Tilia & 7.36 & - \\
Picea & 7.66 & - \\
Fraxinus & 5.23 & 5.83 \\
Thuja & - & 17.09 \\
Prunus & - & 5.83 \\
\hline z The number of trees for street trees represents the total population, while \\
the number for non-street trees represents a sample.
\end{tabular}

exclusively plant trees (and shrubs) native to Ontario and/or North America. For the garden centers and nurseries surveyed, trees made up a relatively limited proportion of their total stock. Most respondents (11 of 12) indicated that trees accounted for less than $25 \%$ of their inventory and sales.

The most commonly selected or suggested genera for planting by the surveyed landscape architects are Acer, followed by Quercus, Gleditsia, Tilia, and Ginkgo (Table 3). The most commonly indicated individual species selected for planting were Ginkgo biloba, Acer rubrum, Quercus rubra, and Gleditsia triacanthos. At the genus level, NPOs also most commonly plant Acer, followed by trees of the Populus genus and then by Quercus (Table 4). Of the total 16 trees listed by the two organizations, only two overlap.

Garden centers and nurseries indicated that a wide variety of tree species and genera were commonly sold (Table 5), but Acer trees are again the most commonly sold trees; Acer palmatum was the most frequently identified species. Though most respondents indicated they sell various tree types (ornamental, coniferous, shade, and hedge varieties), garden-center sales appear to favor primarily ornamental species and genera.

Considering municipal planting, just under 100,000 trees and shrubs were planted in 2012 by Toronto Urban Forestry. This includes plantings in natural areas and ravines (approximately 75,000 trees) and along streets (approximately 22,000 trees) (R. Vendrig, pers. comm., June 3, 2013; October 25, 2013). Toronto's Urban Renewal section generally uses two documents as reference for species selection purposes; both are available online (www. toronto.ca/trees). The first is a brochure available to residents interested in having a free street tree planted. The second is a native tree naturalization list, which is more of an internal reference document that includes more detailed planting information and requirements. Acer and Quercus have a strong presence on these documents, as well as trees

Table 2. Participation rates and characteristics of actors engaged in tree planting in Toronto.

\begin{tabular}{lll}
\hline Actor & $\begin{array}{l}\text { No. of respondents } \\
\text { (\% of potential } \\
\text { participants) }\end{array}$ & Clients or planting areas \\
\hline Landscape architects & $50(45 \%)$ & $\begin{array}{l}\text { Residential most common client-type; commercial and government also } \\
\text { frequently identified }\end{array}$ \\
NPOs & $2(100 \%)$ & $\begin{array}{l}\text { One NPO primarily residential; the other primarily in parks and natural areas. } \\
\text { Primarily private residents; also landscapers, contractors, and developers } \\
\text { Garden centers and nurseries } \\
\text { Toronto urban forestry }\end{array}$ \\
\hline
\end{tabular}


Table 3. Commonly selected genera by landscape architects.

\begin{tabular}{ll}
\hline Species & Identification frequency (\%) \\
\hline Acer & 90 \\
Quercus & 68 \\
Gleditsia & 44 \\
Tilia & 40 \\
Ginkgo & 36 \\
Fagus & 26 \\
Amelanchier & 24 \\
Cornus & 18 \\
Liriodendron & 18 \\
Pinus & 16 \\
Betula & 14 \\
Carpinus & 14 \\
Pyrus & 12 \\
Picea & 10 \\
Robinia & 10 \\
\hline
\end{tabular}

Table 4. Commonly planted species by NPOs. Bold text indicates the species was indicated by both NPOs.

\begin{tabular}{ll}
\hline NPO 1 & NPO 2 \\
\hline Acer rubrum & Acer saccharum \\
Acer saccharum & Acer saccharinum \\
Acer $\times$ freemanii & Carpinus caroliniana \\
Cercis canadensis & Celtis occidentalis \\
Liriodendron tulipifera & Juglans nigra \\
Thuja occidentalis & Liriodendron tulipifera \\
& Ostrya virginiana \\
& Populus balsamifera \\
& Populus deltoids \\
& Populus tremuloides \\
& Quercus rubra \\
& Quercus macrocarpa \\
\hline
\end{tabular}

from the Populus genus. However, these are reference documents and do not reflect the frequency of planting. Table 6 represents a shortened list showing only those species indicated by Toronto Urban Forestry to be the most frequently planted species by the city. These are particularly common for roadway and street tree plantings, whereas in park areas there is greater flexibility for tree species selection due to superior soil quality and the fact that park staff is able to provide a better standard of care. In addition to the species noted in Table 6 , park plantings may also commonly include: London planetrees (Platanus $\times$ acerifolia), yellowwoods (Cladrastis kentukea), purple robe black locusts (Robinia pseudoacacia), and tuliptrees, as well as different evergreens, oaks, and maples (R. Vendrig, pers. comm., June 3, 2013).

When comparing across actors, Toronto Urban Forestry and landscape architects have a high degree of overlap, including Acer, Gleditsia, Tilia, and Gingko. NPO's are planting a wide variety of species and genera as are garden centers. However, for the latter, many of species and genera are small ornamental trees.
Table 5. Commonly sold genera by garden centers.

\begin{tabular}{ll}
\hline Genus & Identification frequency \\
\hline Acer & 11 \\
Syringa & 6 \\
Hydrangea & 5 \\
Buxus & 4 \\
Cornus & 4 \\
Euonymus & 4 \\
Thuja & 4 \\
Betula & 3 \\
Cercis & 3 \\
Fagus & 3 \\
Taxus & 3 \\
\hline
\end{tabular}

Table 6. Tree species most commonly planted by the City of Toronto's Urban Forestry Department.

Acer $\times$ freemanii

Celtis occidentalis

Gleditsia triacanthos inermis "Skyline"

Ginkgo biloba

Gymnocladus dioicus

Tilia americana "Redmond"

Tilia cordata

Ulmus japonica $\times$ wilsoniana

\section{PEST VULNERABILITY RESULTS}

Figure 2 shows the PVM comparing the current street tree population and municipal planting trends. Figure 3 shows current non-street trees and the planting trends of the non-municipal local actors. Because low severity pests are relatively insignificant from an urban forest management perspective, those pest complexes containing no interactions or only low severity ones were removed from the matrices. However, double-lined black boxes around cells indicate pest-tree interactions that were noted by the FHC unit supervisor as being problematic in Toronto despite the pests (often) low severity. Due to public perception, noticeable but otherwise minor aesthetic problems can become severe for an urban forester and may require intervention when the host trees are common (J. Ric, pers. comm., July 31, 2013). It is also important to note that not all species of trees have the same level of susceptibility to a given pest. The two parallel curved lines seen in some cells in the matrices indicate that not all species in the genus in question are susceptible to the pest complex indicated.

Comparing the current composition and planting trends in the matrix allows investigation into where particular vulnerabilities are being maintained, worsened, or alleviated, and whether new problems may be emerging. With street trees (Figure 2), there 
are reductions in vulnerability, while some issues will remain. For severe interactions, there are several concerns that persist from the current population into the planting trends. Specifically, vulnerability to Xylosandrus crassiusculus (Asian ambrosia beetle), Anoplophoraglabripennis (Asian longhorned beetle), and Lymantria dispar (gypsy moth) continue. However, anthracnose complexes, Agrilus planipennis (emerald ash borer), Dematophora root rot, and Cronartium ribicola (white pine blister rust) have no or low vulnerability in the planting trends despite representing severe vulnerability in the current assemblage. Vulnerability to moderate severity pests and diseases also sees a significant decrease in the planting trends from 25 interactions down to eight.

The pest vulnerability for non-street trees is given in Figure 3. There is generally less vulnerability to pests in the planting trends versus the current assemblage, although there are still notable areas of concern. With respect to severe pests, there are more interactions of concern than in the street tree population. Vulnerability to Dematophora root rot, anthracnose, X. crassiusculus, A. glabripennis, and $L$. dispar will continue based on the planting trends. Additionally, beech bark disease and Agrilus anxius (bronze birch borer) are two severe pests emerging in the planting trends. For moderate severity interactions and issues particular to Toronto (those cells with double-lined black boxes), there is a decrease in vulnerability in the planting trends (from 43 interactions to 24), similar to street trees.

\section{DISCUSSION}

The common tree genera in Toronto resemble the genera that are common across many cities in North America: Acer, Fraxinus, Quercus, Gleditsia, Ulmus, Malus, Prunus, and Tilia (Dreistadt et al. 1990; Raupp et al. 2006). This supports the general observation that urban environments, including vegetation, tend to be more homogenous than their non-urban or wild counterparts (McKinney 2002). These common genera are likely prevalent for many reasons, including their historic ability to thrive to maturity in urban environments (i.e., tolerance of soil compaction, pollution, limited space, and road salt; Richards 1983), and potentially because they are also readily available. This latter point should not be overlooked given the strong influence the horticultural industry can have on the species compositions of vegetation communities in urban environments (Pincetl et al. 2013).

Like currently common genera, the trees identified as commonly planted (or sold) in this research are not unique to Toronto. D'Amato and colleagues (2002) found that the most requested tree genera by urban foresters in Ohio included Acer, Quercus, Fraxinus, Amelanchier, Tilia, Ulmus, Pyrus, Malus, Syringa, and Prunus trees-many genera that are represented in the survey and interview responses here.

The patterns of tree planting in Toronto have the potential both to improve species diversity in the urban forest in certain respects while also maintaining the predominance of already common genera. This is particularly true in Toronto's municipally owned street trees; Acer, Tilia and Gleditsia continue to be commonly planted by the city, though in the case of Acer, the specific species now planted (Acer freemanii) is relatively uncommon in the current street tree population. The remaining commonly planted street tree genera are relatively rare in the current assemblage (such as Celtis, Gymnocladus, and Ginkgo) and have the potential to increase diversity.

In the broader urban forest, there is limited overlap between current composition and planting trends. Again Acer is both well established in the population and commonly being planted. Beyond Acer and a few genera common only in one or two management areas in Toronto (e.g., Gleditsia), the currently common and frequently planted genera in non-street trees are fairly divergent (Table 7).

Table 7. Currently common and frequently planted genera for street and non-street tree populations.

\begin{tabular}{llll}
\hline $\begin{array}{l}\text { Street trees } \\
\text { current }\end{array}$ & $\begin{array}{l}\text { Street trees } \\
\text { planting trends }\end{array}$ & $\begin{array}{l}\text { Non-street } \\
\text { tree current }\end{array}$ & $\begin{array}{l}\text { Non-street tree } \\
\text { planting trends }\end{array}$ \\
\hline $\begin{array}{lll}\text { Acer } \\
\text { Tilia }\end{array}$ & Acer & Acer & Acer \\
Gleditsia & Gleditsia & Thuaj & Tilia \\
Picea & Gleditsia & Gleditsia \\
Malus & Celtis & Ulmus & Quercus ${ }^{z}$ \\
Fraxinus & Gymnocladus & Prunus & Ginkgo \\
Pinus & Ginkgo & Pinus & Populus \\
Quercus & & Populus & Syringa \\
& & Picea & Hydrangea \\
& & & Buxus \\
& & & Euonymus \\
& & & Thuja \\
& & & Betula \\
& & & Cercis \\
& & & Fagus \\
& & & Taxus \\
\hline
\end{tabular}

${ }^{\mathrm{z}}$ Genus was indicated by more than one non-municipal actor. 


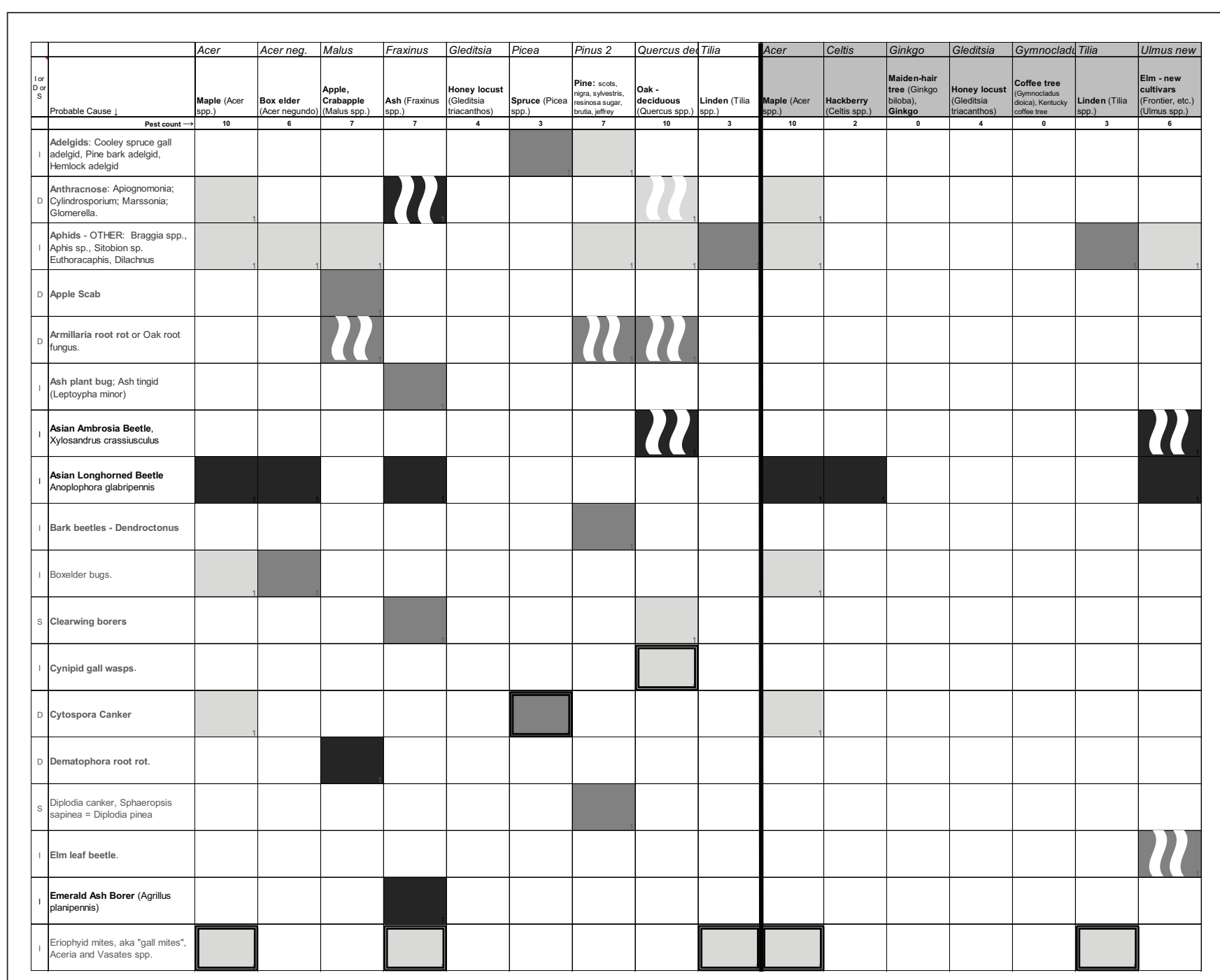

Figure 2. Pest Vulnerability Matrix for street trees comparing current common street trees with municipal planting trends. Columns with grey-toned headers (right) represent the planting trends; columns with white headers (left) represent current species assemblages. Low severity pests are shown in light gray, moderate severity in medium gray, and severe pests in dark gray. The parallel white curved lines indicate not all the individual species in the genus are susceptible to the given pest. Black text indicates an invasive non-native species of pest or disease. I, D, and S represent insect, disease, or secondary condition. Black, double-lined boxes indicate pest-tree interactions noted as problematic in Toronto due to public perception of pest and frequency of genera.

Based on the results from the PVM, overall pest vulnerability is likely to decrease in the future for Toronto's urban forest, with the number of both severe and moderate severity interactions decreasing. However, some significant concerns remain. For both the current and future urban forest composition, the most concerning issues are typically from invasive non-native tree pests and diseases. These results concur with findings by the City of Toronto; Urban Forestry considers A. glabripennis, L. dispar, A. planipennis, and Ceratocystis ulmi (Dutch elm disease) to form some of the biggest risks for Toronto's urban forests with the potential to do over six billion dollars of structural damage to the forest (City of Toronto 2011).

Agrilus planipennis is currently a major focus of the city's FHC unit. It is assumed that every single ash tree in Toronto is now infested and that by 2017 only ash trees that have been treated will remain standing (J. Ric, pers. comm., July 10, 2013). The FHC is implementing a coordinated management plan where thousands of city-owned ash trees in good condition showing low levels of infestation are being treated with injections to halt or slow the progress of the 


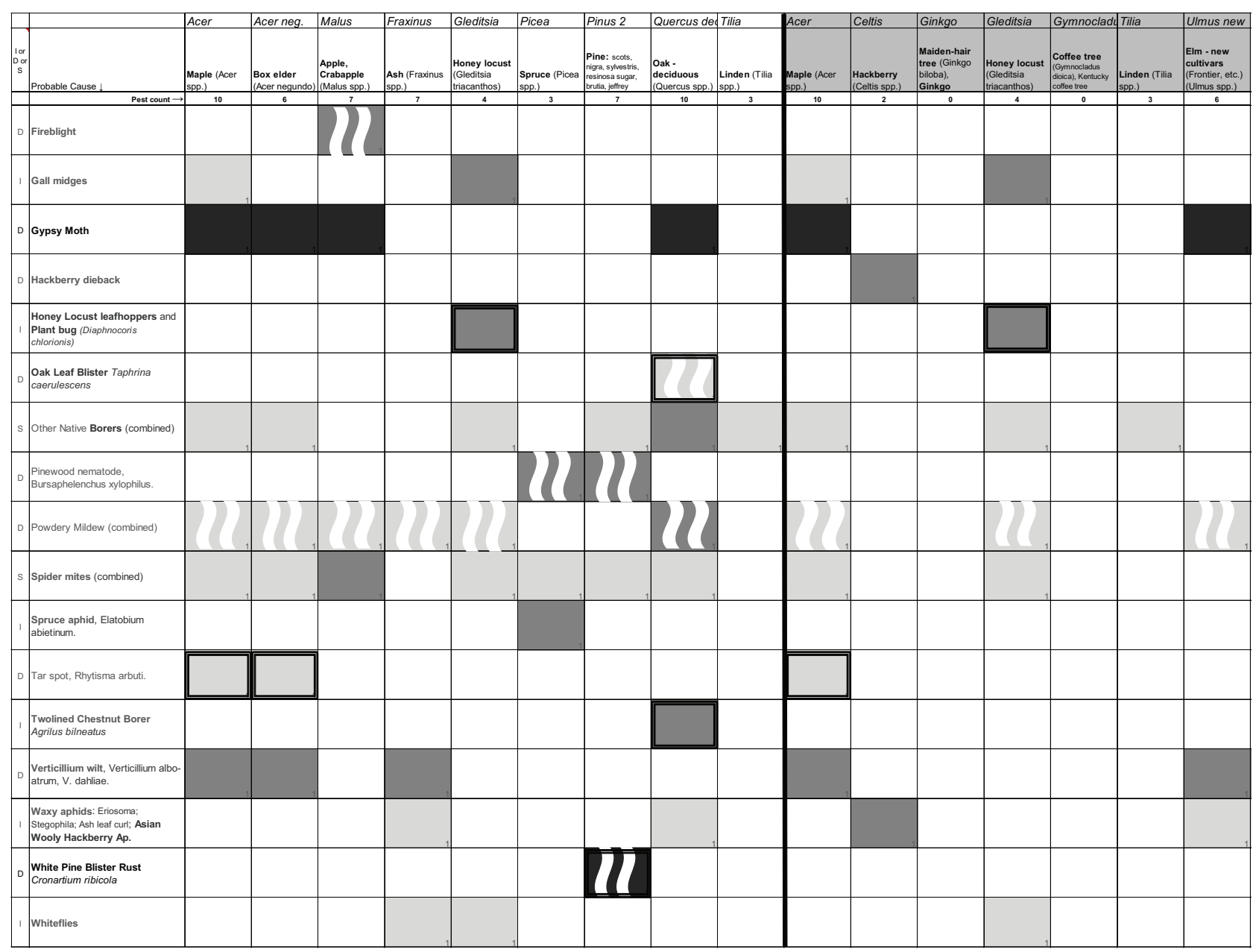

borer (J. Ric, pers. comm., July 10, 2013). The effect of $A$. planipennis on privately owned trees might be more severe than for city-trees, as private property is not subject to a coordinated management plan and many landowners will likely defer treatment. Moving into the future, the magnitude of this pest's impact will decline as ash is no longer commonly planted or sold in Toronto. Given the publicity of this pest, it is not surprising that ash trees have been removed from planting lists and inventories.

For Toronto and in fact Ontario and Canada at large, A. glabripennis is particularly concerning from a vulnerability perspective. Although the invasive borer was deemed eradicated from Canada by the Canadian Food Inspection Agency (CFIA) in April 2013 (CFIA 2013a), it was discovered again outside the eradication zone in September 2013 in Mississauga, Ontario (CFIA 2013b), a short distance from the City of Toronto. Maples are a preferred host to A. glabripennis and given the high proportion of the genus in the street and non-street tree populations (plus the other susceptible hosts from less common genera), Toronto's urban forest is extremely vulnerable to high levels of loss due to this pest. Total poten- 


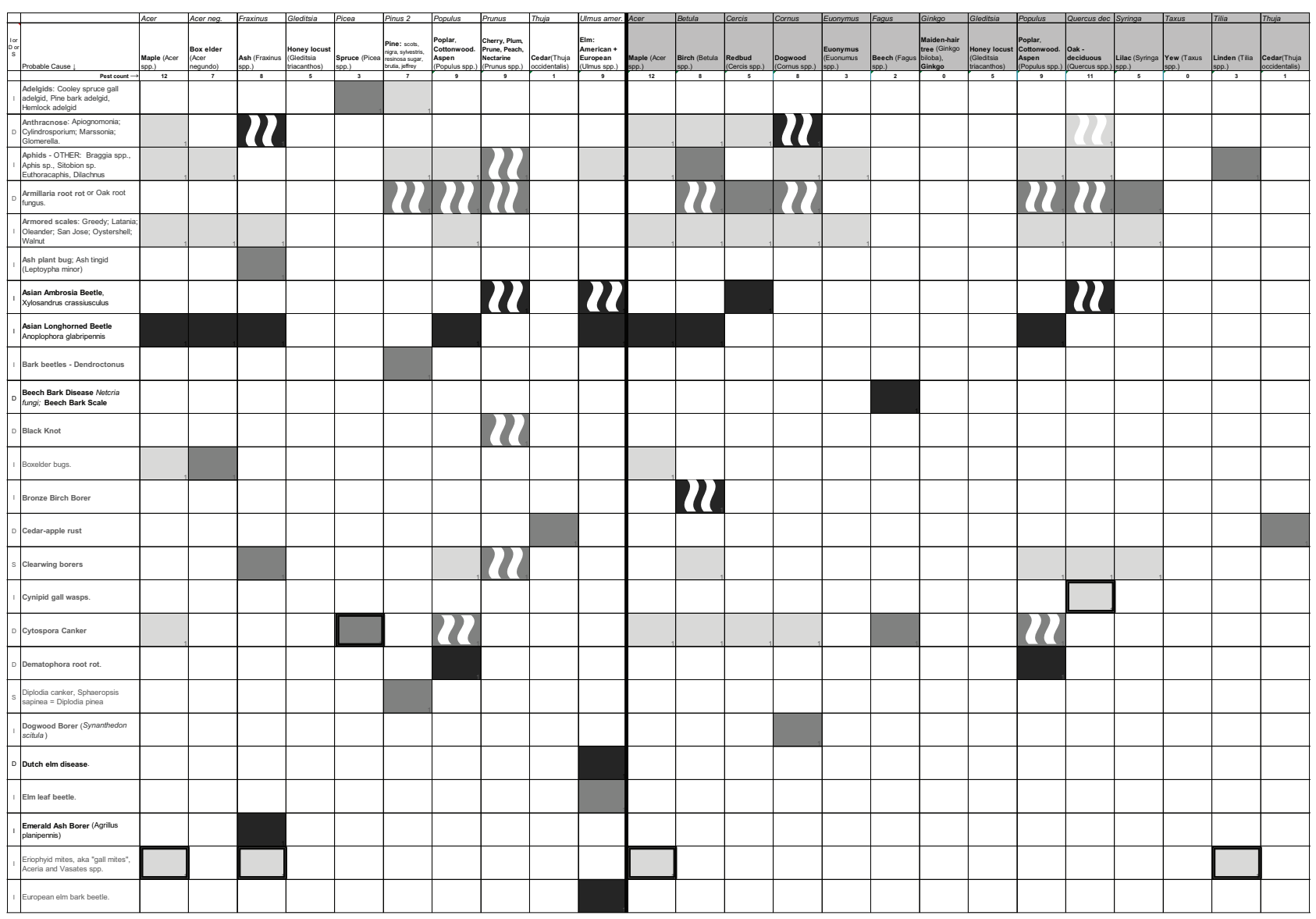

Figure 3. Pest Vulnerable Matrix for non-street trees comparing current species composition with planting trends. Refer to Figure 2 for legend.

tial losses in structural value have been estimated at CAD $\$ 4$ billion (City of Toronto 2011). Lymantria dispar will also likely continue to be a problematic pest in Toronto and require coordinated intervention from the city (through aerial spraying and egg-mass removal) every few years (J. Ric, pers. comm., July 10, 2013). Lymantria dispar and A. glabripennis are especially problematic because they are polyphagus and feed on multiple tree families, making it difficult to avoid all susceptible genera in new plantings.

An additional concern stems not from known threats, but from the fact that some already common genera continue to be planted regularly. Though Tilia and Gleditsia have few pests to which they are susceptible (see Figure 2), and currently have no severe interactions, they are quite common in the street tree population and continue to be planted with high frequency. In the constantly changing landscape in which urban forests now exist, the potential for new pests with strong impacts on these genera cannot be eliminated or necessarily predicted. As such, efforts should be made to maintain proportions of these genera at or below $10 \%$ throughout the city. Where the genus is predominated by a single species, such as Gleditsia, the proportion should be kept in-line with the 5\% guideline for single species.

While few genera are above the $10 \%$ threshold in Toronto's urban forest, there is still cause for working to increase the diversity in both the street and nonstreet tree populations. Plantings of Acer should be scaled back as they dominate the landscape and also appear to be the most commonly planted and sold genera in the city. As the inverse SDI values show, there is room for improvement for genera diversity in both populations, but particularly for street trees. Reducing reliance on Acer and substituting 


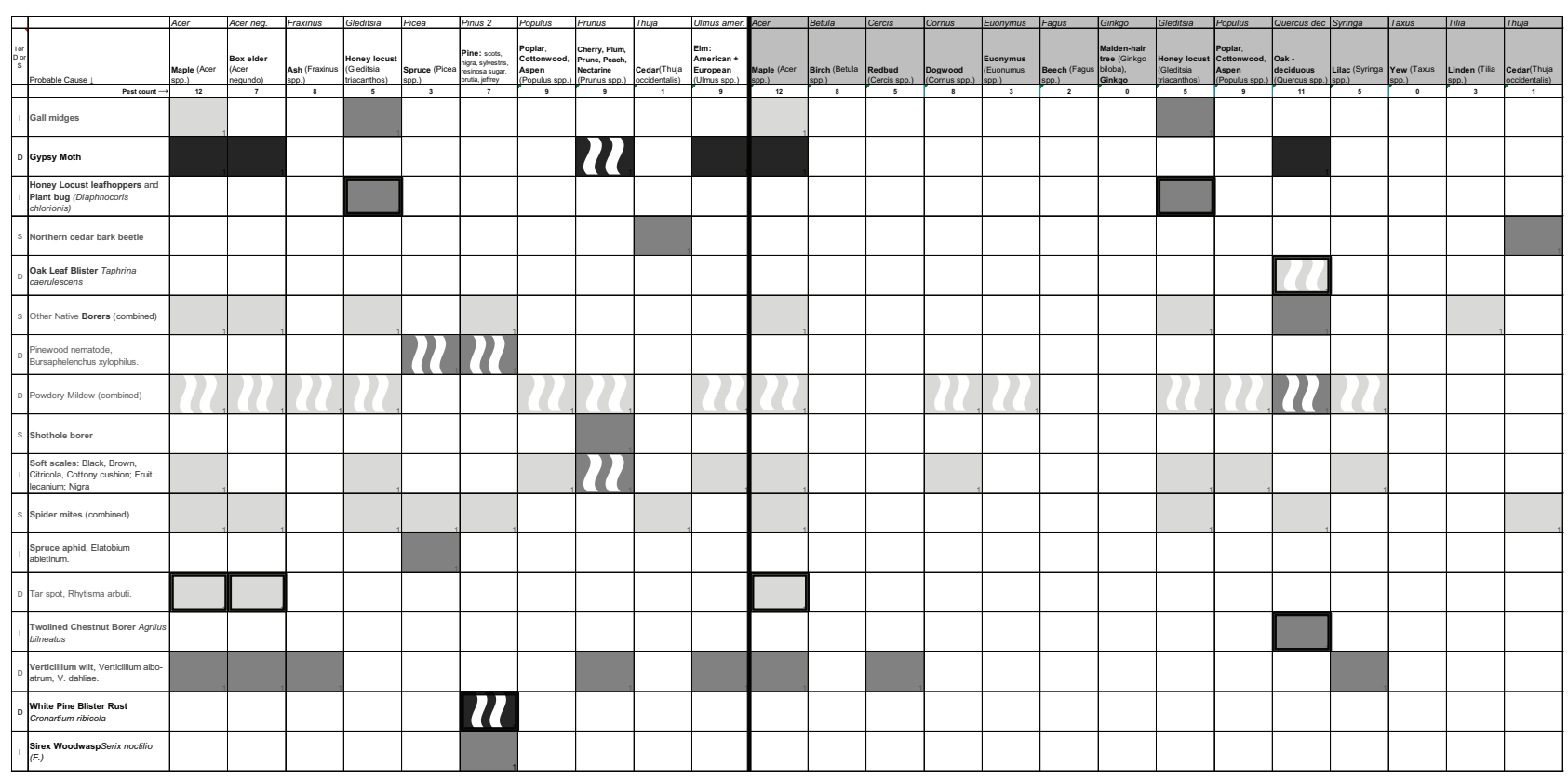

it with uncommon or under-utilized genera will help to increase the forest's overall diversity value.

More steps could be taken to further decrease pest vulnerability by addressing the limited presence of coniferous trees. Discounting Thuja, because of their primary use as hedge species, only Picea make up more than $5 \%$ of either the street or non-street tree populations citywide. Though not above $5 \%$ citywide in either population, Pinus is also common in one management district of Toronto. Compounding the current low coniferous diversity, the trees most commonly planted by all actors surveyed or interviewed are overwhelmingly deciduous. The only coniferous genera noted were Taxus and Thuja by a handful of garden centers and nurseries. In Jactel and Brockerhoff's (2007) meta-analysis investigating insect herbivory and tree stand diversity, their findings showed an increased resistance to herbivory where there is a mixture of broadleaf and coniferous trees. Pest vulnerability potentially could be further reduced in Toronto if more coniferous trees were planted in both street and non-street populations.

Another step to help reduce pest vulnerability is to decrease the amount of ornamentals planted. Ornamentals tend to be more susceptible to pests, causing primarily aesthetic issues, but these minor issues can become larger problems due to public concern (J. Ric, pers. comm., July 10, 2013). Ultimately, they can cost more in terms of management and care, as well as in mortality and replacement.

It is important to acknowledge the limitations of this work. Examining these topics at the citywide scale likely misses important intracity spatial variation that exists both in current composition and planting trends. Additionally, the use of a sample, rather than a complete tree inventory for non-street 
trees likely overlooks some rare species. However, such omissions would likely only have minimal effects on the relative dominance of the most common species and would not represent major concerns from a pest-vulnerability perceptive. With regard to the tree planting data, while the results represent the planting activities of a variety of important actors participating directly or indirectly in urban forest management, they are not comprehensive of all tree plantings occurring in Toronto. The results are also based on individuals' perceptions of what genera and species they most commonly planted or sold. It would be worthwhile to further investigate actual tree purchasing and planting records. There are limitations with the generalizability of these results, but this work represents a good first look into the overall picture of what is being planted in the City of Toronto and how it will likely influence pest vulnerability.

Additionally, it is important to note that pest vulnerability, and the use of a tool like the PVM, is only one of many components to urban forest management. Understanding overall pest vulnerability and the ways current planting trends are affecting that vulnerability should be one of several considerations when planting and maintaining the urban forest. Pest issues are also influenced by more than the presence (or lack) of susceptible hosts-there are many other relevant aspects to consider. For example, maintaining a diverse age structure is important as tree age can influence susceptibility to, and the ultimate impact of, a pest or disease. It is also important to have complex and appropriate vegetation structure so that birds and other beneficial organisms are attracted to, and can thrive in, urban environments and help control problematic pest populations.

In summary, Toronto's urban forest will likely see a decrease in vulnerability to tree pests moving into the future based on the genera that are now frequently planted. Invasive, non-native pests continue to be a major source of concern and vulnerability for the urban forest. Likewise, the over-dominance of and heavy reliance on a few genera are problematic. In general, the diversity of both street and non-street tree populations could be improved, in part, through increasing the proportion of coniferous trees, reducing the number of ornamentals, and relying less on the standard urban tree genera like Acer, Tilia, and Gleditsia.
Acknowledgments. This research was supported by the Social Sciences and Humanities Research Council through the JosephArmand Bombardier Canada Graduate Scholarships-Master's award. The authors would also like to thank all the individuals who took the time to participate in the surveys and interviews for this research. Special thanks to Igor Laćan for providing the original PVM and to J. Ric of the Forest Health Care unit in Toronto's Urban Forestry department for his help with modifying the PVM for Toronto.

\section{LITERATURE CITED}

CFIA. 2013a. Asian Long-horned beetle eradicated from Canada. News Release. Accessed 12/18/2013. <www.inspection.gc.ca/ about-the-cfia/newsroom/news-releases/2013-04-05/eng/1365 168144940/1365168154936>

CFIA. 2013b. Asian long-horned beetle found in Mississauga. News Release. Accessed 12/18/2013. <www.inspection.gc.ca/aboutthe-cfia/newsroom/news-releases/2013-09-20/eng/1379685062 $894 / 1379685078216>$

City of Toronto. 2011. Every tree counts: a portrait of Toronto's urban forest. Accessed 03/27/2014. <www1.toronto.ca/City\%20 Of\%20Toronto/Parks\%20Forestry\%20\&\%20Recreation/ Urban\%20Forestry/Files/pdf/E/every_tree_counts.pdf>

City of Toronto. 2012. Street tree general data [Metadata file]. Parks, Forestry \& Recreation and Urban Forestry, Toronto, Ontario, Canada.

City of Toronto. 2013a. Toronto's geography. Accessed 03/27/2014. <www.toronto.ca/toronto_facts/geography.htm>

City of Toronto. 2013b. Urban Forestry: Forest Heath Care. Accessed 03/27/2014. <www1.toronto.ca/wps/portal/conte ntonly?vgnextoid=17f4cacb759e0410VgnVCM10000071d6 0f89RCRD>

Czerwinski, E., J. Pollard, and T. Scarr. 2006. Forest health alert: Sirex Woodwasp [Sirex noctilio (F.)]. Accessed 05/23/2013. $<$ www.mnr.gov.on.ca/en/Business/Forests/2ColumnSubPage/ STEL02_166996.html>

D’Amato, N.E., T.D. Syndor, and D.K Struve. 2002. Urban foresters identify Ohio's tree needs. Journal of Arboriculture 28:291-301.

Dillman, D.A. 2007. Mail and internet surveys: The tailored design method, second edition. Jon Wiley and Sons, Toronto, Ontario, Canada.

Dreistadt, S.H., D.L. Dahlsten, and G.W. Frankie. 1990. Urban forests and insect ecology. BioScience 40:192-198.

Dykstra, M.D., and M. Sabourin. 2012. Pests and diseases of the eastern white cedar (Thuja occidentalis). Report no. PDCF-006 of the Pest Diagnostic Clinic. Accessed 05/22/2013. <www. guelphlabservices.com/files/PDC/006Eastern\%20White\%20 Cedar.pdf>

Escobeder, F.J., T. Kroeger, and J.E Wagner. 2011. Urban forest and pollution mitigation: Analyzing ecosystem services and disservices. Environmental Pollution 159: 2078-2087.

Farrar, J.L. 1995. Trees in Canada. Fitzhenry \& Whiteside Limited and the Canadian Forest Service, Markham, Ontario, Canada.

Gamfeldt, L., T. Snäll, R. Bagchi, M. Jonsson, L. Gustafsson, P. Kjellander, M.C. Ruiz-Jaen, et al. 2012. Higher levels of multiple ecosystem services are found in forests with more tree species. Nature Communications 4:1340.

Haack, R.A., and R.E. Acciavatti. 1992. Two-lined Chestnut Borer: Forest Insect and Disease Leaflet 168 of the US Department of 
Agriculture Forest Service. Accessed 05/22/2013. <www.na.fs. fed.us/spfo/pubs/fidls/chestnutborer/chestnutborer.htm>

Harwood, T.F., I. Tomlinson, C.A. Potter, and J.D. Knight. 2011. Dutch elm disease revisited: Past, present, and future management in Great Britain. Plant Pathology 60:545-555.

Jactel, H., and E.G Brockerhoff. 2007. Tree diversity reduces insect herbivory by forest insects. Ecology Letters 10:835-848.

Kershaw, L. 2001. Trees of Ontario. Lone Pine Publishing, Edmonton, Ontario, Canada. 240 pp.

Laćan, I., and J.R. McBride. 2008. Pest vulnerability matrix (PMV): A graphic model for assessing the interaction between tree species diversity and urban forest susceptibility to insects and diseases. Urban Forestry \& Urban Greening 7:291-300.

McKinney, M.L. 2002. Urbanization, biodiversity, and conservation. BioScience 52:883-890.

Natural Resources Canada. 2011. Dogwood anthracnose. Accessed 05/23/2013. <www.exoticpests.gc.ca/es-details/disease/1000095>

Nowak, D.J. 2012. Contrasting natural regeneration and tree planting in fourteen North American cities. Urban Forestry \& Urban Greening 11:373-382.

OMNR. 1991. Common Pests of Trees in Ontario. Accessed 12/02/2013. <www.mnr.gov.on.ca/stdprodconsume/groups/ lr/@mnr/@forests/documents/document/stel02_179226.pdf>

Pincetl, S., S.S. Prabhu, T.W. Gillespie, G.D. Jenerette, and D.E. Pataki. 2013. The evolution of tree nursery offerings in Los Angeles County over the last 110 years. Landscape and Urban Planning 118:10-17.

Plant Disease Diagnostic Clinic. 2013. Oak Leaf Blister. Accessed 05/22/2013. <http://plantclinic.cornell.edu/factsheets/oakleafblister.pdf $>$

Poland, T.M., and D.G. McCullough. 2006. Emerald ash borer: Invasion of the urban forest and the threat to North America's Ash resource. Journal of Forestry 104:118-124.

Raupp, M.J., A. Buckelew Cumming, and E.C Raupp. 2006. Street tree diversity in Eastern North America and its potential for tree loss to exotic borers. Arboriculture \& Urban Forestry 32:297-304.

Richards, N.A. 1983. Diversity and stability in a street tree population. Urban Ecology 7:159-171.
Schall, M.J., and D.D. Davis. 2009. Ailanthus altissima wilt and mortality: Etiology. Plant Diseases 93:747-751.

Sinclair, W.A., H.H Lyon, and W.T. Johnson. 1987. Diseases of Trees and Shrubs. Cornell University Press, Ithaca, New York, U.S.

Sjöman, H., J. Östberg, and O. Bühler. 2012. Diversity and distribution of the urban tree population in ten major Nordic cities. Urban Forestry \& Urban Greening 11:31-39.

Subburayalu, S., and T.D. Sydnor. 2012. Assessing street tree diversity in four Ohio communities using the weighted Simpson index. Landscape and Urban Planning 106:44-50.

Sun, W.Q. 1992. Quantifying species diversity of streetside trees in our cities. Journal of Arboriculture 18:91-93.

Tyrväinen L., S. Pauleit, K. Seeland, and S. De Vries. 2005. Benefits and uses of urban forest and trees. pp. 81-115. In: C.C. Konijnendijk, K. Nilsson, T.B. Randrup, and J. Schipperijn (Eds.). Urban Forests and Trees: A Reference Book. Springer, New York City, New York, U.S.

Vannatta, A.R., R.H. Hauer, and N.M. Schuettpelz. 2012. Economic analysis of emerald ash borer (Coleoptera: Buprestidae) management options. Journal of Economic Entomology 105:196-206.

Waldron, G. 2003. Trees of the Carolinian Forest. Boston Mills Press, Erin, Ontario, Canada.

Jennifer Vander Vecht

Department of Geography

University of Toronto - Mississauga

3359 Mississauga Road North

Mississauga, Ontario L5L 1C6

Canada

jennifer.vandervecht@mail.utoronto.ca

Tenley M. Conway (corresponding author)

Department of Geography

University of Toronto - Mississauga

3359 Mississauga Road North

Mississauga, Ontario L5L 1C6

Canada

tenley.conway@utoronto.ca 
Zusammenfassung. Urbane Wälder repräsentieren eine wertvolle Resource für Städte, aber nicht ohne Kosten zu verursachen. Diese Kosten können Zeit, Geld und den Verlust der vorteilhaften Dienstleistungen als Ergebnis von Schädlingsinvasionen einschließen. Kenntnisse der Artenzusammensetzung in urbanen Wäldern und der Anfälligkeit gegenüber Schädlingen sind erforderlich, um den Managern zu helfen, den gelieferten Service zu verbessern und langfristig die Kosten zu senken. Die jüngste Forschung hat den Einfluss von individuellen Schädigern in urbanen Wäldern erforscht, aber es wurde weniger Aufmerksamkeit auf die allgemeine Anfälligkeit gerichtet. In dieser Forschung wurden Baumarten, die weit verbreitet und häufig in Toronto, Ontario, Kanada, gepflanzt werden, unter Verwendung einer Schädlingsanfälligkeitsmatrix analysiert um herauszubekommen wie sich die Baumartenzusammensetzung und die Anfälligkeit verändert. Gegenwärtige Baumartenzusammensetzungen wurden den Daten aus den aktuellen Baumkatastern entnommen, während die Trends bei der Pflanzung durch eine Auswahl lokaler Unternehmen durch Fragebögen und Interviews bestimmt wurden. Die Ergebnisse zeigen, dass es eine etwas begrenzte Zusammensetzung in Strassenbaum- und Nicht-Strassenbaumpopulationen gibt, genau wie eine Anzahl von gewöhnlichen Baumarten, die ernste Anfälligkeiten gegenüber Schädlingen aufweisen. Während neue Pflanzungen einige Themen um Zusammensetzung und Anfälligkeiten gegenüber Schädlingen aufgreifen, werden aber auch viele weniger verbreitete Arten gepflanzt. Als Ergebnis sollte die allgemeine Anfälligkeit gegenüber Schädlingen in der Zukunft abnehmen, während einige Management-Bedenken bleiben.
Resumen. Los bosques urbanos representan un recurso valioso para las ciudades pero no están exentos de costos. Estos costos pueden incluir el tiempo, el dinero y la pérdida de servicios beneficiosos como resultado de las infestaciones por plagas. Es necesario conocer la composición de especies de árboles de un bosque urbano y la vulnerabilidad a las plagas para ayudar a los administradores a mejorar los servicios prestados y reducir al mínimo los gastos a largo plazo. Las investigaciones recientes han explorado los efectos de las plagas individuales en los bosques urbanos, pero se ha prestado poca atención a la vulnerabilidad general de plagas. En esta investigación, se analizaron géneros de árboles actualmente prevalecientes y comúnmente plantados en Toronto, Ontario, Canadá, mediante una matriz de vulnerabilidad a plagas para explorar cómo la composición de especies del bosque urbano de la ciudad y de la vulnerabilidad de plagas pueden estar cambiando. La composición de las especies de árboles actual se deriva de los datos de inventario existentes, mientras que las tendencias de plantación de una variedad de actores locales se determinaron a través de encuestas y entrevistas. Los resultados indican que hay diversidad algo limitada en las poblaciones de árboles la calle y los que no están en la calle, así como un número de especies de árboles comunes que tienen vulnerabilidades severas de plagas. Mientras que las nuevas plantaciones replican algunos problemas de composición y de la vulnerabilidad de plagas actuales, varias especies menos comunes también se están plantando. Como resultado, la vulnerabilidad general de plagas debe disminuir en el futuro, mientras permanecen algunas de las preocupaciones de manejo. 